\title{
The Phenomenon of "Badapu" Tradition with Nutritional Status in Postpartum Mothers in West Aceh
}

\author{
Zakiyuddin*, Fitrah Reynaldi \\ Faculty of Public Health, Universitas Teuku Umar, Meulaboh, Aceh, Indonesia \\ *Corresponding authorE-mail: zakiyuddin@utu.ac.id
}

Manuscript received 1 Jan 2021; revised 10 Jan 2021; accepted 15 Jan 2021. Date of publication 20 Jan 2021

\begin{abstract}
Cultural practices negatively affect public health behavior, making it more likely to have an infection. In Aceh there is a tradition applied to post-partum mothers called Madeung, which is a tradition carried out by women after giving birth for 44 days with a variety of applicable provisions. The purpose of this study was to determine the nutritional status of postpartum mothers based on the phenomenon of carrying out the tradition of "Badapu" as an effort to improve nutrition for postpartum mothers in West Aceh. This type of research is explanatory survey or explanation aimed at studying the patterns of consumption of traditional food "Badapu" in West Aceh (quantitative) and people's perceptions of traditional food Badapu (qualitative). The planned design is one group before and after intervention design, or one group pre and post test design. The results obtained illustrate the pattern of food consumption in postpartum mothers who carry out the tradition of Badapu, which varies slightly and is almost the same every day with the main menu of rice, eggs and fried fish. All postpartum mothers (100\%) consume rice as a food source of carbohydrate as the biggest energy contributor. At least puerperal mothers who eat snacks because there are restrictions on being able to consume these foods. The existence of restrictions on postpartum mothers who carry out the tradition of Badapu to consume several types of food ingredients that contain water, which is generally found in vegetables and fruits.
\end{abstract}

Keywords: Badapu, Postpartum, Mothers, Nutrition

\section{Introduction}

Maternal mortality, used as a measure of success towards achieving MDGs-5, is a 75\% reduction in the maternal mortality ratio. In poor countries, around $25-50 \%$ of deaths of women of childbearing age are caused by problems related to pregnancy, childbirth and the puerperium. WHO estimates that around the world every year more than 585,000 die during pregnancy or childbirth [8].

In developed and developing countries, the main concern for mothers and babies is too much focused on pregnancy and childbirth, while the real situation is precisely the opposite. Postpartum hemorrhage is the main cause of 150,000 maternal deaths every year in the world and nearly 4 out of 5 deaths due to postpartum bleeding [5].

In the community of West Aceh, there is also a culture or tradition of abstinence from eating certain foods which are determined to the post-partum mother, namely the Badapu tradition. This tradition is carried out by postpartum mothers starting on the seventh day to the 60th day for the birth of the first child and 40 days for the next child. When carrying out the tradition of Badapu, postpartum mothers are prohibited from consuming several types of food ingredients such as eggs, shellfish, shrimp, tuna, milk, papaya, banana, pineapple, and chili as well as fruits which are considered to contain a lot of water such as oranges, watermelons and etc. This tradition has been going on for generations from the past until now and this has resulted in the intake of postnatal maternal nutrition being less when compared with the adequacy of nutrition needed by mothers for postpartum recovery and preparation for breastfeeding. Postpartum mothers should get more food in terms of quantity and quality, so they can produce milk to meet the needs of infants.

However, because it is required to carry out the tradition of Badapu, the puerperal mother follows the existing rules of limiting certain types of food that can be eaten. As a result of these restrictions, food consumed by postpartum mothers does not meet the recommended nutritional adequacy rates. This Affects the nutritional status of the mother which will indirectly have an impact on the growth and development of her baby who is in need of good and nutritious milk from the mother to help the optimal process of the first thousand days of her life. Another impact arising from the culture of abstinence from eating to post partum mothers is anemia. The first cause of anemia during childbirth is due to infection, especially for mothers who have had bleeding during labor, a very long delivery process or the mother may have anemia during pregnancy and then this is made worse by abstinence from eating during the postpartum period. will experience severe anemia [9]. 
Lack of knowledge about nutrition and one side of maintaining tradition in them is also one of the causes of women of childbearing age who will later do the Badapu tradition. Nutrition education during pregnancy and childbirth can actually be given to women of childbearing age from an early age so that they will be able to prepare themselves to undergo childbirth later. Because tradition does not have to be eliminated but can be done together with the progress of science and technology. For example the tradition of drinking raw drinks, stoneware and restoring the condition of the mother's stomach and genital devices using hot stones can continue to be done but the mother must eat according to nutritional recommendations for postpartum mothers without restrictions.

\section{Methods}

This type of research is a survey with explanatory type or explanation aimed at studying the patterns of consumption of traditional food "badapu" and the relationship of nutritional intake of post partum mothers who carry out the tradition of "badapu" with the nutritional status of postpartum mothers in West Aceh (quantitative) and people's perceptions of Badapu traditional food (qualitative).

The planned design is one group before and after intervention design, or one group pre and post test design this is described systematically as follows :

$\mathrm{E}$

$\mathrm{O} 1$

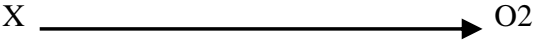

Information :

$\mathrm{E}:$ The group that got the intervention

O1 : First Observation

O2 : Second Observation

X : Intervention (Murti,1997)

In quantitative research, the population is mothers giving birth after thirty days who carry out the tradition of Badapu in May-July 2018 in West Aceh District. The entire population will be sampled in the study (total sampling) as many as 45 people. Whereas in qualitative research, the sample that participated was postpartum mothers, mother / in-laws, village midwives, village midwives and traditional leaders, totaling 26 people. Sampling was done by purposive with certain considerations and limitations of effort, money and time.

\section{Results and Discussion}

\subsection{Result}

Eating patterns or food habits found in a community can be scrutinized, among others, through the presence of food restrictions or restrictions or taboo. Typically, this taboo food is intended for young children, pregnant women and nursing mothers.

Community consumption patterns can show the level of community food diversity. From this food consumption pattern will give an idea of the type and frequency of food consumed by respondents during carrying out the tradition of Badapu. More clearly can be seen in table 1 below.

Table 1. Frequency Food Form

\section{Consumption frequency}

\begin{tabular}{|c|c|c|c|c|c|c|c|c|c|c|}
\hline \multirow[t]{2}{*}{ Food Name } & \multicolumn{2}{|c|}{ 1-3x/days } & \multicolumn{2}{|c|}{ 4-5x/days } & \multicolumn{2}{|c|}{$\begin{array}{c}1- \\
3 x / \text { month }\end{array}$} & \multicolumn{2}{|c|}{ Never } & \multicolumn{2}{|c|}{ information } \\
\hline & $\mathrm{n}$ & $\%$ & $\mathrm{n}$ & $\%$ & $\mathrm{n}$ & $\%$ & $\mathrm{n}$ & $\%$ & $\mathrm{n}$ & $\%$ \\
\hline Staple food : a. Rice & 45 & 100 & 0 & 0 & 0 & 0 & 0 & 0 & 45 & 100 \\
\hline b. noodles & 0 & 0 & 0 & 0 & 0 & 0 & 0 & 0 & 0 & 0 \\
\hline c. bread & 0 & 0 & 0 & 0 & 0 & 0 & 0 & 0 & 0 & 0 \\
\hline d. Biscuit & 0 & 0 & 0 & 0 & 0 & 0 & 0 & 0 & 0 & 0 \\
\hline Side dishes : a. Chicken & 5 & 11 & 4 & 8.8 & 35 & 78 & 1 & 2.2 & 45 & 100 \\
\hline b. Meat & 0 & 0 & 2 & 4 & 43 & 96 & 0 & 0 & 45 & 100 \\
\hline c. Egg & 38 & 84.4 & 5 & 11 & 2 & 6 & 0 & 0 & 45 & 100 \\
\hline d. Fish & 20 & 45 & 20 & 45 & 5 & 10 & 0 & 0 & 45 & 100 \\
\hline e. Shrimp & 4 & 9 & 11 & 24 & 30 & 67 & 0 & 0 & 45 & 100 \\
\hline f. Squid & 5 & 12 & 8 & 17 & 32 & 71 & 0 & 0 & 45 & 100 \\
\hline g. Tempe/tahu & 10 & 22 & 32 & 71 & 3 & 7 & 0 & 0 & 45 & 100 \\
\hline Vegetables : a. Spinach & 1 & 2 & 20 & 45 & 23 & 51 & 1 & 2 & 45 & 100 \\
\hline b. Carrot & 0 & 0 & 11 & 25 & 34 & 75 & 0 & 0 & 45 & 100 \\
\hline
\end{tabular}




\begin{tabular}{lcccccccccc} 
c. Bean & 0 & 0 & 13 & 29 & 32 & 69 & 0 & 0 & 45 & 100 \\
\hline d. Kentang & 0 & 0 & 2 & 5 & 43 & 95 & 0 & 0 & 45 & 100 \\
\hline e. Sweet potato leaves & 0 & 0 & 19 & 42 & 26 & 58 & 0 & 0 & 45 & 100 \\
\hline f. Kale & 5 & 11 & 30 & 66 & 10 & 23 & 0 & 0 & 45 & 100 \\
\hline Fruit : a. Lemon & 2 & 6 & 8 & 17 & 35 & 77 & 0 & 0 & 45 & 100 \\
\hline b. Banana & 5 & 11 & 1 & 2 & 39 & 87 & 0 & 0 & 45 & 100 \\
\hline c. Papaya & 0 & 0 & 3 & 7 & 42 & 93 & 0 & 0 & 45 & 100 \\
\hline d. Watermelon & 0 & 0 & 1 & 2 & 44 & 98 & 0 & 0 & 45 & 100 \\
\hline e. Aplle & 1 & 2 & 4 & 9 & 40 & 89 & 0 & 0 & 45 & 100 \\
\hline
\end{tabular}

Primay Data 2019

The data above shows the food consumption patterns of postpartum mothers when carrying out the tradition of Badapu vary slightly because every day they consume rice, eggs and fish, only a few are supplemented with plant foods, vegetables and fruits. All (100\%) of respondents consume rice as a staple food source of carbohydrates. As suggested that postpartum mothers should eat additional food to meet the nutritional needs of the mother during breastfeeding.

Consumption of protein sources from animal foods in general is eggs (84.4\%). As many as $45 \%$ of respondents who consume fish. While those who consume meat, shrimp, squid and tempeh are only a small part, namely around $19 \%$ of respondents.

Vegetables that are often consumed are angkong, as much as 200 gr / day. Only a small proportion of respondents (30\%) consume vegetables every day at lunch and dinner only.

Fruit consumption is very low. Only a small proportion of respondents $(<5 \%)$ consume oranges and apples daily with an amount of approximately 200 gr / day (day and night).

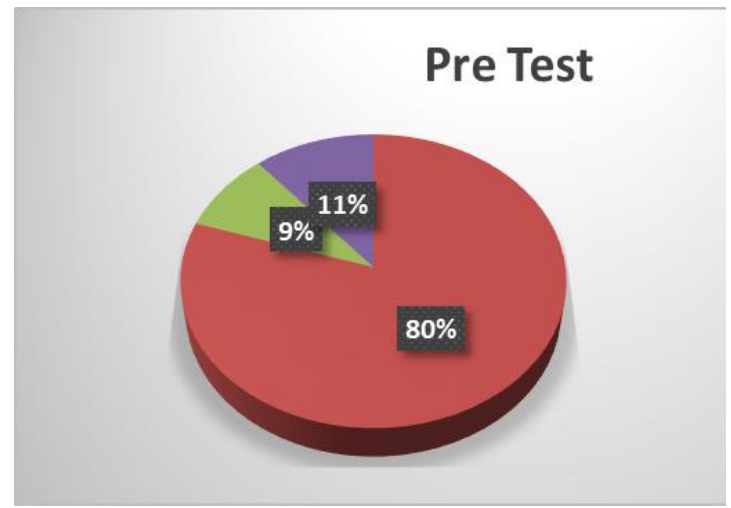

Fig 1. Diagram 1

Based on diagram 1 above, it can be seen that the majority of respondents at the pre-test had a normal Body Mass Index of $80 \%$, more weight as much as $11 \%$ and less weight as much as $9 \%$.

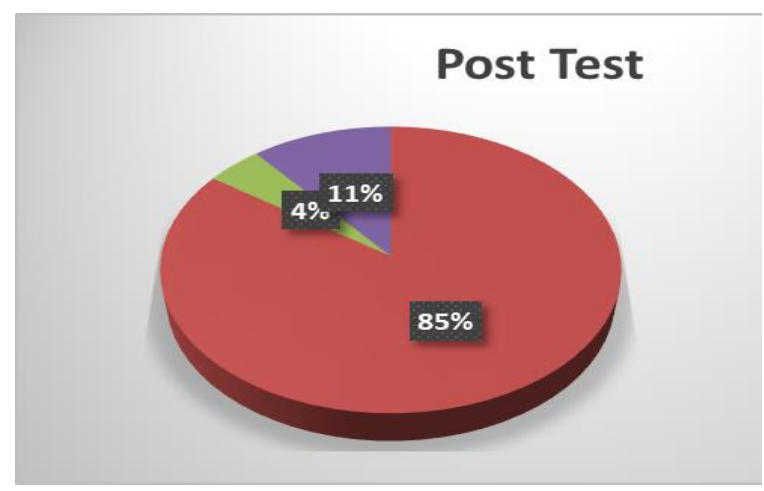

Fig 2. Diagram 2

Based on diagram 2 above, it can be seen that the majority of respondents during the Post Test still had a normal Body Mass Index of $85 \%$, more weight as much as $11 \%$ and less weight as much as $4 \%$.

\section{Community Perceptions of Badapu Traditions}

Public perception of Badapu traditional food is obtained from the opinion of the community of 26 people, represented by 8 (eight) postpartum mothers, 8 (eight) mothers / mothers-in-law, 4 (four) village midwives, 4 (four) village midwives 4 (four) people and traditional leaders as much as 2 (two) people who were taken purposively by $20 \%$. 


\section{On whose initiative the tradition of Badapu is carried out}

From interviews with the initiative to carry out the tradition of Badapu, the following opinions were obtained: as many as 10 people stated at the initiative of parents (Mother or Mother-in-law) because the postpartum mother had just given birth to the first child so that the initiative to carry out the tradition of Badapu from parents; 11 people stated that at the initiative of the parents and the post-partum mother because the post-partum mother had carried out the tradition of Badapu, so she had the desire to carry out the tradition of Badapu at the birth of the next child which was also supported by the parents; as many as 3 people stated at the initiative of the postpartum mother herself because the postpartum mother carried out the tradition of Badapu without the assistance of parents at the birth of the next child; and 2 people stated at the initiative of parents and village midwives because parents and village midwives played a large role in the implementation of the tradition of Badapu.

"Badapu is an initiative of parents because it has been passed down from their ancestors". "Badapu is of its own and parents' wishes to follow existing traditions". "I live this tradition because I have done it to my children before" "The tradition of Badapu is carried out on the initiative of parents and midwives / village shamans".

\section{Do you agree to carry out the tradition of Badapu}

From the interview results it is known that as many as 21 people agreed to carry out the tradition of Badapu and only 5 people who did not agree to the implementation of the tradition of Badapu

The following are excerpts from interviews from several informants, namely:

"Must agree to the tradition of Badapu which has been carried down for generations". "Oh, I personally strongly disagree with the implementation of the tradition of Badapu"

\section{Reasons for agreeing or not to carry out the tradition of Badapu.}

Based on the results of interviews, it is known that the reasons for agreeing to carry out the tradition of Badapu are because the tradition of Badapu is beneficial for health, so that the body is healthy and recovers quickly or can restore and restore the body's condition to normal.

The following are excerpts from interviews from several informants, namely:

"Badapu to recover and restore the body to normal". "With the body, the body becomes healthy and strong (not weak), can sweat so the body becomes fresh". "With a healthy body, quickly recover as before". As for reasons that do not agree to carry out the tradition of Badapu because it is contrary to the health or unhealthy method, Badapu has no benefit because it is troublesome and too rigid.

The following are excerpts from interviews from several informants, namely:

"I do not agree because the tradition of Badapu limits the intake of nutrients, by prohibiting postpartum mothers from consuming certain types of food." "Badapu tradition is very troublesome and too rigid with a variety of rules".

\section{Foods that may be eaten while carrying out the tradition of Badapu.}

Opinions about foods that can be eaten by postpartum mothers while carrying out the tradition of Badapu, namely: rice; fried / grilled fish to dry so that the uterus and female organs dry quickly and other types of food are prohibited for consumption; chicken; meat; tempeh; Tofu; vegetables (cassava leaves, katu leaves, long beans, spinach), fruits that do not contain much water (oranges, apples, bananas) so that the female tool dries quickly, "raw drinks" and "pariuk drinks"

The following are excerpts from interviews from several informants, namely:

"Food that can be eaten only rice and fish fried / grilled only." "Foods that can be eaten by people who are Badapu namely rice, fried / grilled fish, chicken, tempeh, tofu, boiled vegetables (cassava leaves, katu leaves and long beans mixed) for lunch and dinner". "Mothers who are unable to eat rice, dried fried fish, vegetables (the water is squeezed), stoneware and raw drinks".

\section{Food that should not be eaten while carrying out the tradition of Badapu}

From the results of the interview, it was found out that food that should not be eaten is a type of food that can have adverse effects on both mother and baby. Tuna, anchovies, venomous fish (catfish, rays, sharks, marang, sebaung), shrimp, crabs, eggs because they can cause itching. Spread vegetables (kale), vegetables that contain gas (jackfruit, cabbage, ferns, mustard greens) because they can cause the stomach of a mother and a bloated baby. Fruits that contain a lot of water (papaya, watermelon, pineapple, guava water) because they slow down the process of restoring female organs. Chili and coconut milk which can cause baby diarrhea.

The following are excerpts from interviews from several informants, namely:

"Foods that should not be eaten by postpartum mothers, namely tuna, eggs, shrimp, windy vegetables (cabbage, ferns, kale) fruits that contain lots of water (pineapple, papaya, watermelon), chili or spicy". "Foods that should not be eaten are meat, fish processed with coconut milk or water, chili". "Foods that should not be eaten are venomous fish (sharks, rays, marang, sebaung), fish / shellfish, shrimp, gassed vegetables (cabbage, mustard, kale) fruits (papaya, watermelons, ) because they are cold, chili, coconut milk and cold water. "

\section{Food when carrying out the tradition of Badapu}

Opinions about food when carrying out the tradition of badapu generally state that there are several types of food that are either forbidden or prohibited, and postpartum mothers must obey the rules, so as not to negatively impact the health of mothers and babies. Food for postpartum mothers who carry out the tradition of Badapu must be able to provide a heat effect or in warm conditions and avoid cold food ingredients because the postpartum mother's body is in cold conditions.

The following are excerpts from interviews from several informants, namely:

"Food for post partum mothers who are Badapu is different from food for ordinary women, it is not allowed to eat chili and coconut milk to interfere with the digestion of the baby so the baby has diarrhea". "Mother childbirth must eat foods that are hot (such as pepper, durian) to restore peranakan. 
Food is eaten warm and should not be cold because the mother's body is cold ". "Badapu food is full of rules and different from ordinary people's food. There are special foods and drinks made for postpartum mothers who are in Badapu, namely rice lancing, pariuk drinks and raw drinks.

\section{Benefits of Badapu tradition for postpartum maternal health}

From the interviews it can be seen that the tradition of Badapu has benefits for postpartum maternal health including cleansing the dirty blood in the stomach, wounds after giving birth and the genitals becoming dry quickly and returning to normal. The body becomes healthy, fresh, fragrant and strong because a lot of sweat comes out from drinking "Pariuk drinks" and "raw drinks". However, there are also those who claim that the tradition of Badapu is of no benefit because the body is supported by fire, which can cause the body to dry out.

The following are excerpts from interviews from several informants, namely:

"The benefits of Badapu are cleaning dirty blood and genitals that dry quickly and come back tight". "The benefits of the body are fresh, light, sweat comes out so that the pores close together". "With the body becoming healthy, bleeding white / dirty and drying the wound in the stomach after giving birth". "The tradition of Badapu is of no use because it has to be found near the fire so that the body is dry."

\section{Advice on the tradition of Badapu}

From the interviews it was found that 19 people suggested that the tradition of Badapu must be continued, because it was for good and health. As many as 5 people suggested that the good continue and the good is eliminated. There is one person who suggests that the tradition of Badapu does not need to be done because of the hassle and unclean. One person suggested that the Badapu tradition be phased out because it was difficult to erase it quickly

The following are excerpts from interviews from several informants, namely:

" We recommend that the tradition of Badapu be phased out because it is difficult to erase it quickly" "The tradition of Badapu must be continued, because for good and health". "Badapu tradition does not need to be done because it is bothersome and unclean". "Good traditions are passed on, bad ones are not eliminated". "We recommend that the tradition of Badapu be phased out because it is difficult to erase it quickly"

\section{Mother's feeling in carrying out the tradition of Badapu}

From interviews specifically for postpartum mothers it was found out that 4 people expressed their normal feelings when carrying out the tradition of Badapu, as many as 2 people were happy to carry out the tradition of Badapu, one person felt relaxed and one person felt bored carrying out this Badapu tradition.

The following are excerpts from interviews from several informants, namely:

"My feeling in carrying out the tradition of Badapu is normal". "In carrying out the tradition of Badapu, I feel happy." "I live this tradition of Badapu by just relaxing". "The tradition of this Badapu, for me is very boring".

\subsection{Discussion}

Based on interviews with postpartum mothers who carry out the tradition of Badapu using the frequency of food, the results obtained give an overview of the consumption patterns of postpartum mothers who carry out the tradition of Badapu. The pattern of food consumption in postpartum mothers who carry out the tradition of Badapu varies slightly and is almost the same every day with the main menu of rice, eggs and fried fish. All postpartum mothers (100\%) consume rice as a food source of carbohydrates as the biggest energy contributor. At least puerperal mothers who eat snacks because there are restrictions on being able to consume these foods.

Animal food is the most widely consumed source of protein every day is fish (84.4\%) because fish is a major side dish that is easy to obtain and does not cause adverse effects on the health of postpartum mothers and their babies.

Food patterns in Indonesia, most of the population uses rice as a staple food. Among animal side dishes, the Indonesian population eats relatively more fish than meat and eggs. Average consumption of vegetables is still low, as well as consumption of fruits is also still low (Almatsier, 2009).

\section{Conclusion}

The existence of restrictions / restrictions on post-partum mothers who carry out the tradition of Badapu to consume several types of food ingredients that are cold or contain lots of water, which are generally found in vegetables and fruits. Therefore, puerperal mothers should avoid foods that are cold and consume foods that are hot or warm.

Instruct Village Midwives to provide proper nutrition education information and direction communication in carrying out the tradition of Badapu on a regular basis to the community, especially to groups of women and community leaders, in the selection and processing of nutritious food ingredients so as to create families and communities that are aware of nutrition. Health workers are also expected to motivate pregnant women to want to take Fe tablets so they do not experience anemia in the face of childbirth.

\section{References}

[1] Adriani dan Wirjatmadi. Peranan Gizi dalam Siklus Kehidupan. Kencana. Jakarta. 2012.

[2] Almatsier, S. Prinsip Dasar Ilmu Gizi. PT Gramedia Pustaka Utama. Jakarta. 2001.

[3] Deri, F : Kajian Konsumsi Makanan Tradisi Badapu Dan Status Gizi Ibu Nifas Di Kecamatan Singkil Kabupaten Aceh Singkil. Dibuka Pada Situs http://repository.usu.ac.id/handle/123456789/6953. 2009.

[4] Notoatmojo S. Metodologi Penelitian Kesehatan. Jakarta: Rineka Cipta; 2010.

[5] Prawirohardjo S, Ilmu Kebidanan. Jakarta: Bina Pustaka. 2008.

[6] Suprabowo, Praktik Budaya dalam Kehamilan dan Nifas. Diakses dari http://jurnalkesemas.ui.ac.id diakses pada atnggal 08- februari 2018. 
[7] Lembaga Adat dan Kebudayaan (LAKA) Daerah Istimewa Aceh. Pedoman Umum Adat Aceh, Edisi I. Banda Aceh : Lembaga Adat dan Kebudayaan. 1990.

[8] Depkes. RI. Perjalanan Menuju Indonesia Sehat. Penerbit Departemen Kesehatan RI. Jakarta;2004. h 20-25

[9] Harnany, AS. Pengaruh Tabu Makanan, Tingkat Kecukupan Gizi, Konsumsi Tablet Besi, dan Teh Terhadap Kadar Hemoglobin Pada Ibu Hamil Di Kota Pekalongan. Program Pascasarjana Universitas Diponegoro Semarang. 2006.

[10] WHO. Media center: maternal mortality, Diakses dari www.who.int/gho/maternal.health/en/. 2018. 